\title{
ANDRZEJ BogusŁAWsKi
}

\section{Do kwestii ,stałych lingwistycznych" Czy „stała interpretacyjna” 'wiesz, o czym mówię’?}

Słowa klucze: stała logiczna; stała lingwistyczna; kondensacja treści; alternatywa

K e y w o r d s : logical constant; linguistic constant; condensation of content; alternative

Muszę na początku powiedzieć, co mam na myśli, podnosząc „kwestię stałych lingwistycznych". Otóż odwołuję się do hasła stała lingwistyczna, które uczynił na naszym gruncie przedmiotem specjalnych rozważań w kilku cennych pracach Profesor Jerzy Pogonowski.

Profesor Pogonowski powiązał to hasło explicite $\mathrm{z}$ dobrze znanym w filozofii języka oraz w logice i metalogice pojęciem „stałej logicznej”. Wysunął on hasło „stała lingwistyczna” jako wyrażenie, które ze względu na te właśnie oczywiste filozoficzne asocjacje może podsunąć jakieś istotne koleiny myślenia o sprawach bardzo ważnych - ważnych dla języka, dla lingwistyki i, ogólniej, dla teoretycznej refleksji nad językiem. Profesor Pogonowski nie traktuje tego wyrażenia jako gotowego terminu technicznego mającego ogólnie przyjęte dobrze określone miejsce $\mathrm{w}$ jakimś równie jasno wyodrębnionym układzie pojęć; bo takiego ogólnie przyjętego terminu nie ma. Ma on na widoku mo $\dot{z} l i$ we roztrząsania, których zaczynem, czy też wstępnym, pro- 
gramowym, punktem wyjścia, dałoby się uczynić tę nazwę, nazwę treściowo w oczywisty sposób nieobojętną.

Tak się dzieje w nauce niejednokrotnie. Jako pierwsze przychodzi do nas czyste wyrażenie, zasadniczo unilateralne, tyle że wraz z takim czy innym kłębkiem asocjacji. Wyczuwamy, że mo że mu odpowiadać jakiś przyzwoicie określony aspekt rzeczywistości obiektywnej; i zastanawiamy się, co dałoby się do tego wyrażenia w sposób poważny dopasować, tak iżby na tej drodze wskazać coś naprawdę istotnego.

Profesorowi Pogonowskiemu chodziło o rozważenie inspiracji, jakie mogą płynąć dla lingwistyki z tego, co się mówi o „stałych logicznych”. Przy czym dostrzegał on wielokierunkowość takich możliwych inspiracji. Nie może to dziwić, bo z wyjściowym hasłem „stała logiczna” wiążą się różne ujęcia.

Ścisły sposób użycia tego hasła jest bardzo prosty: jest to nagłówek określonej listy symboli w tym czy innym rachunku logicznym, które nie należą do tzw. „,zmiennych” (lub znaków interpunkcyjnych takich jak nawiasy). Lista taka może być dość arbitralna. W praktyce uprawiania logiki to znakomicie wystarcza.

Ale zestawianiu listy stałych logicznych, inaczej niż na przykład koncypowaniu figur szachowych wraz z ich relacjami wzajemnymi, towarzyszy zarazem rozumienie tego, że odgrywają one rolę bynajmniej nie zabawową, że mają służyć zadaniom dotyczącym tak centralnej sprawy, jak wiedza, że odpowiadają one jakimś filarom rzeczywistości obiektywnej.

Stąd nie jest przypadkiem, że czystej technice dotyczącej stałych logicznych towarzyszą próby znalezienia jakichś uogólnień ich dotyczących, opracowania ich jakiejś „filozofii”. Ajdukiewicz w swej Logice pragmatycznej (1965: 97-98) upatrywał ogólną naturę stałych logicznych w tym, że ich właściwości przejawiają się z koniecznością we wszelkich językach i w całej nauce. Brzmi to bardzo przekonywająco. Czyż można nazwać dziedzinę w ogóle niedotykającą sprawy istnienia określonych obiektów oraz nieistnienia pewnych ich podrodzajów - dziedziną działania jakichś języków albo też dziedziną obejmującą naukę, nie naruszając przy tym w jaskrawy sposób samego sensu wyrazów język, nauka? A przecież w tak typowych stałych logicznych, jak kwantyfikatory, chodzi właśnie o istnienie i nieistnienie.

Ale już w tym miejscu, w obrębie fragmentu logiki, jaki stanowią dwa klasyczne kwantyfikatory, szczegółowy i ogólny, powstaje problem: jaka jest relacja między nimi? Może któryś z nich jest podstawowy, a drugi ma cha- 
rakter pochodny? Wówczas zarysowuje się jakaś możliwa gradacja „stałości” stałych logicznych, a wraz z nią pojawia się myśl, że warto jest może mówić o jakichś absolutnych stałych, a więc o „stałości” w innym, mniej technicznym sensie niż ten, jaki ma zwykłe wyliczenie przyjmowanych narzędzi rachunkowych.

Taki modus rozważań o stałych logicznych jest w oczywisty sposób pokrewny Leibniziańskiemu nurtowi poszukiwania ,alfabetu myśli ludzkich”, czyli nurtowi ogólnego redukcjonizmu pojęciowego. Właściwie trudno jest nawet te obszary rozdzielić. Przypomnijmy, że skrótowe wysłowienie programu Leibniza brzmiało: Reducenda omnia alia ad ea quae sunt absolute necessaria ad sententias animi exprimendas (podkr. moje).

Ten nurt Leibniziański ma naturę na tyle ogólną, że obejmuje i to, co dotyczy logiki, i to, co dotyczy języka naturalnego. Kiedy prof. Pogonowski mówi o tym, że je dn a z możliwości wprowadzenia lingwistycznej paraleli w stosunku do stałych logicznych jest po prostu próba ustalenia pewnej puli wyrażeń, które mają charakter treściowo elementarny i uniwersalny (co przypomina ujęcie Ajdukiewicza), to dotyka on czegoś, co z pewnością miał na widoku właśnie Leibniz. Oczywiście do tej tematyki odnoszą się też znane przedłożenia Anny Wierzbickiej.

W tym związku mógłbym od siebie przypomnieć, że ja uważam za ostateczna ,stałą”, i logiczną i lingwistyczną, universale wszystkich języków naturalnych $\mathrm{w}$ postaci jednego funktora, funktora wie o_, że_, nie: (oczywiście w jego każdorazowych postaciach dźwiękowych). Cała reszta, np. dysjunkcja, kwantyfikacja, to w moich oczach nic innego jak inherentnie tkwiące w funktorze wie, że jego a spekty.

W obecnej wypowiedzi chciałbym się jednak zająć innym możliwym rozumieniem ,stałych lingwistycznych” niż ich rozumieniem jako czegoś, co równa się treści wyrażeń elementarnych. Ku takiemu innemu rozumieniu kieruje też $\mathrm{w}$ większym stopniu naszą uwagę prof. Pogonowski.

Chodzi o takie cechy zarówno kodowych instrumentariów języków naturalnych, jak i ich funkcjonowania, które bądź są nieodłączne od samego pojęcia języka naturalnego i są, eo ipso, powszechne, bądź są przynajmniej powszechne de facto.

Prof. Pogonowski rozważa cały wachlarz takich cech. Tylko dla zgrubnego zorientowania $\mathrm{w}$ tym, co ma na myśli prof. Pogonowski, podam dwa 
przykłady rozważanych przez niego licznych hipotez dotyczących ewentualnych „stałych lingwistycznych”. Pierwszą niech będzie „wykluczenie inwersji jako wykładnika negacji” (moim zdaniem, hipoteza i ważna i dająca się doskonale uzasadnić), drugą - „konieczna obecność zaimków deiktycznych” (rozumiałbym przez to demonstrativa i relativa; znowu hipoteza zasługująca na uznanie).

Ze swej strony chciałbym się zastanowić - pokrótce i bardzo wstępnie nad jednym tylko kandydatem do roli cechy uniwersalnej w podobnym stylu. Kandydata tego wskazałem w tytule swego wystąpienia.

Moja refleksja skupi się na początek na przykładzie pewnej sprawy dobrze znanej z dyskusji semantycznych i pragmatycznych. Chodzi o użycie wyrażeń reprezentujących w takim czy innym uwikłaniu kwantyfikację ogólną. Niech ich przedstawicielem będzie tu ,zaimek” wszyscy. Interesować mnie będzie takie interesujące badaczy jego użycie, kiedy mówiący ewidentnie nie wyklucza tego, że niektóre obiekty należące do kręgu przewidzianego przez kod, w naszym przykładzie wszyscy - do kręgu 'osób', wymykają się jednak charakterystyce przez niego wprowadzonej. Może być nawet tak, iż mówiący wręcz przesądza, że takie wyjątki istnieja, a mimo to nie powstrzymuje się od użycia naszego zaimka. I, rzecz to główna w naszym rozważaniu, mówiący nie odczuwa przy tym (i słusznie!) żadnej obawy, że mu ktoś zarzuci fałsz (czy zgoła kłamstwo).

Rozważmy wypowiedź (1):

(1) Wszyscy w naszej rodzinie wiedzą, że Jurek się wyprowadził z domu.

Chodzi o sytuację, kiedy jest na przykład jasne, że prababcia mimo wszystko nie wie o tym. Zasadniczą sprawą, o którą mi chodzi, jest fakt, że autora zdania (1) nie da się, wbrew temu, co mogłoby komuś przyjść do głowy, uznać za 'kłamcę’ (oczywiście: za „niewinnego kłamcę”). Prawdziwym „niewinnym kłamcą” jest ktoś, kto powie, że przyszedł tam a tam o piątej, podczas gdy faktycznie przyszedł tam o g. 5.01. Natomiast autor zdania (1) na ,podchwytliwe” zapytanie: „Prababcia też o tym wie?”, odpowie prawdomównie, a przede wszystkim trafnie: „Nie brałem jej pod uwagę.”. 
Jak należy zinterpretować ten niewątpliwie problematyczny przypadek? Otóż moim zdaniem wypada tu zastosować to samo rozwiązanie, co w wypadku zdania

(2) Kazik MA troje dzieci.,

które mówi o Kaziku niekoniecznie mającym tylko troje dzieci. Na czym ono polega? Na tym, że ,gołe frazy liczebnikowe”, takie jak nasza fraza troje dzieci, uznajemy za podające równoliczność p e w n e g o zbioru nieliczbowego (tu: „dzieci Kazika”) z odpowiednim zbiorem liczbowym (jako zbiorem kolejnych elementów szeregu arytmetycznego, tu: 1,2, 3), ale równocześnie za przewidujące arbitralne, zgodne $z$ aktualna intencja mówiącego, granice owego zbioru nieliczbowego. Ten zbiór można określić, ze stanowiska mówiącego, np. autora zdania (2), w następujący sposób: „te obiekty, o których myślę”. Unikamy w ten sposób jakiegokolwiek „kognitywnego” rozmywania granic między semantyką a pragmatyką. W odniesieniu do przykładu (2) powiemy, że $i$ semantycznie i pragmatycznie ws zystko jest w porządku z Kazikiem, zarówno wtedy, kiedy „Kazik” spłodził tylko troje dzieci, jak i wtedy, kiedy ogółem spłodził 500 dzieci. Bo mówiący może mieć na myśli jedyną trójkę dzieci Kazika, ale może też mieć na myśli którąkolwiek trójkę z jego 500 dzieci.

Powiem teraz coś, co stanie się swoistą trampoliną wiodącą do mojej zasadniczej propozycji. Powiem mianowicie rzecz następującą: Państwo wiecie, o czym mówi autor zdania (2), i Państwo wiecie, o czym ja mówię, kiedy mówię, że w zdaniu (2) wszystko jest w porządku z Kazikiem (nawet jeżeli ma on 500 dzieci). Bo przecież nie zdziwicie się Państwo, że nie podejmę polemiki z kimś, kto ogłosi, iż nie było to całkiem w porządku ze strony Kazika, kiedy płodził (powiedzmy) 357 ze swoich 500 dzieci.

Jaka więc jest moja propozycja? Sformułuję ją tak: należy rozważyć kwestię istnienia w języku naturalnym pewnej cechy jego funkcjonowania, która, być może, zasługuje na miano stałej lingwistycznej w takim sensie, o jakim tu mówimy, w sensie „universale”, a której głównym wysłowieniem jest ta właśnie fraza, której przed chwilą użyłem: wiesz, o czym mówię (za jej odpowiednik angielski wypadałoby uznać frazę you know what I mean). Tę idio- 
matyczną frazę uważam za najlepsze sformułowanie ewentualnej stałej, jaką mam na widoku.

Ale można oczywiście rzecz ująć w formie bardziej „,naukawej”. Możemy mianowicie powiedzieć tak: bazowy, informacyjny tok wypowiedzi skierowanej do zewnętrznego adresata zawsze zaklada, $\boldsymbol{i}$ t $\boldsymbol{o}$ zak $\boldsymbol{k} \boldsymbol{a} \boldsymbol{d} \boldsymbol{a} \boldsymbol{z} \boldsymbol{g} \boldsymbol{o} \boldsymbol{d}$ nie z prawda, rozumienie tej wypowiedzi przez adresata welni odpowiadające zamiarowi nadawcy (to ujęcie motywuje wybór nazwy wskazany w tytule: stała in te r pre ta cyjna).

Ważne jest przy tym wskazane ograniczenie całej sprawy do owych bazowych, informacyjnych użyć języka, tzn. użyć w trybie 'mówienia, że', lub stanowiących ich uzupełnienia nieoznajmujące (por. np. zwykłe użycia rozkaźnika). Do nich mogą należeć, dodam, także przypadki, kiedy informacja jest podawana pośrednio, w drodze użyć metaforycznych lub metonimicznych, a choćby i żartobliwych. Ograniczenie, o które mi chodzi, polega na wyłączeniu z sensownego komentarza 'wiesz, o czym mówię' wszelkich wypowiedzi jawnie nieasertorycznych, cytacyjnych, literackich i podobnych. Wynika stąd, że fraza wiesz, o czym mówię jest daleka od redundancji - w odróżnieniu na przykład od ewentualnego prefiksu mówię, który byłby dopuszczalny przy wszystkich wypowiedziach i odpowiednio do tego całkowicie zbędny. Nasycenie informacyjne klauzuli, którą tu rozpatrujemy, udobitnia dodatkowo fakt następujący: w pewnych sytuacjach można ją z dobrym sensem zanegować. Por. np. zdanie filozofa francuskiego Ch. Secrétana:

(3) Jestem tym, czego chcę.;

gdyby Secrétan był szczery, zaprezentowałby to zdanie, dodając: nie wiesz, o czym mówię. Jeszcze jeden przykład:

(4) Spread pozwoli ci uniknąć strat finansowych; na razie nie wiesz, o czym mówię.

(wiele osób przyklaśnie takiej właśnie wypowiedzi).

Zwróćmy teraz uwagę na kolejną okoliczność o kluczowym znaczeniu. Mianowicie: trafne przesądzenie trafnego rozumienia wypowiedzi przez adresata jest przeważnie implicytne. Co więcej, musi być takie. Musi być 
takie pod grozą - w większości wypadków - jaskrawej dewiacji. Por. wypowiedź (5):

(5) Janek jest chory.

padającą w zwykłych okolicznościach. Wypowiedź (5) - w zwykłych okolicznościach - nie toleruje dodania wiadomej frazy (wiesz, o czym mówię). Zarazem rzeczą zasadniczą jest fakt, że dewiacyjność jej dodania nie wynika ze sprzeczności lub pleonastyczności z nią związanej: bo jej treść jest tu nie tylko na miejscu; jest ona nawet, w puli zwykłych użyć (ca. 100\%), bezapelacyjnie prawdziwa. To właśnie ta kombinacja okoliczności pasuje treść 'wiesz, o czym mówię' na stałą lingwistyczną (tak jak to pojęcie tu potraktowaliśmy).

Jednocześnie treść, o której mówimy, w pewnych wypadkach rzeczywiście $\mathrm{w}$ sposób bezdyskusyjny ujawnia się materialnie w postaci akceptowalnych osobnych zdań lub wtrąceń o kształcie wiesz, o czym mówię lub podobnym. Kiedy więc twierdzę, że taka szczególna treść istnieje, nie zgłaszam jakiegoś czczego postulatu. Jako przykład podam wypowiedź (6):

(6) Ten kran się krztusi; wiesz o czym mówię.

W tym przykładzie chodzi o sytuację rzetelnie informacyjną; nawet jeżeli jest ona sytuacją użycia metaforycznego (metaforycznego ,aktualnie”, nie: „genetycznie”). (Oczywiście „stałość” treści naszej frazy “wiesz, o czym mówię' wyklucza obligatoryjność jej eksplicytnego użycia gdziekolwiek; chodzi tu tylko o niedewiacyjność (6).)

Dodam teraz krótki, ale z metodologicznego punktu widzenia bardzo ważny komentarz. Dyskutowaną w tym miejscu klauzulę 'wiesz, o czym mówię' wprowadzałem osobno do reprezentacji semantycznych różnych konkretnych wyrażeń. Dziś jestem skłonny uważać takie posunięcie za niewłaściwe.

W pewnych wypadkach, być może, jest ono naprawdę konieczne (np. w odniesieniu do wyrażenia to jest ... [nie: w sensie 'to znaczy / tzn. / tj.'], któremu poświęciłem bardzo obszerne studium). Ale, ogólnie rzecz biorąc, 
nasza stała lingwistyczna ,z góry” towarzyszy wszelkim reprezentacjom semantycznym i nie powinna już być w nich osobno powtarzana.

Wydaje się, że bardzo korzystne byłoby tu rozważenie niezwykle kluczowego w języku wyrażenia o polskim kształcie tylko, któremu słusznie poświęciła wiele uwagi prof. Jadwiga Wajszczuk. Ale jego analiza jest osobnym wielkim zadaniem, na którego nawet najkrótszą próbę rozwiązania nie ma tu miejsca. Posłużę się innym przykładem. Będzie to polska partykuła zwłasz$c z a$, np. w zdaniu (7):

(7) Ona lubi zwłaszcza róże.

Zdanie to może dotyczyć ukochanej albo malarki. O co w nim chodzi? Chodzi o wyróżnienie pewnej nieobojętnej z punktu widzenia mówiącego p o d k la s y właściwej określonej klasy obiektów (powiedzmy, klasy lubianych przez „nią” kwiatów). Ale k tó r ej podklasy? Tej, którą nadawca w jakikolwiek sposób, tzn. z dowolnego punktu widzenia, przypisuje ,nieobojętność"; przy czym chodzi o podklasę, co do której nadawca zakłada, że to przypisanie „nieobojętności” i tylko to przypisanie odbiorca podstawi na miejsce pojęcia 'wiesz, o czym mówię / wiesz, że istnieje podklasa kwiatów przez „niego” lubianych związana z konsekwencjami, które są nieidentyczne z konsekwencjami innych podklas tej klasy'. Moim zdaniem, nadawca nie wprowadza tu żadnej innej treści. To zaś, o co mu rzeczywiście chodzi (jak to właśnie wyłożyłem), wyczerpuje ,ryczałtowo”, bez żadnego wchodzenia w szczegóły, w sposób taki sam, jaki obserwujemy we wszystkich wypowiedziach informacyjnych, właśnie nasza ,stała interpretacyjna”.

To, co tu przedkładam, ma, trzeba zauważyć, wagę niezwykle ogólną. To właśnie w naszej „stałej interpretacyjnej” ma się zawierać ogólna, ,antycypacyjna”, by tak rzec, „dyspensa” na ws z el ki e skróty i kondensacje, tak jak są one niemal bez żadnych granic realizowane w mowie (por. np.:

(8) Do. / Z.

w odpowiedzi na pytanie: Jedziesz z Poznania czy do Poznania?). 
Ostatnia uwaga o charakterze ogólnoteoretycznym. Taka „stała”, jak tu koncypowana, może być pochodną czegoś bardziej pierwotnego (dla stałych logicznych tego rodzaju relacja bywa dopuszczana).

Otóż w naszym wypadku swoista derywacja zachodzi w stosunku do dwóch głównych filarów języka.

Pierwszym z nich jest istnienie dwóch poziomów rzeczywistości językowej: poziomu podstawowego, poziomu 'mówienia, że', gdzie właśnie zakłada się wspólnotę interpretacji prawdziwościowej nadawcy i adresata, i poziomu wtórnego, gdzie takiej wspólnoty może nie być, lecz który to wtórny poziom nie może w ogóle istnieć - bez tamtego poziomu, bez owej bazy.

Drugi filar prezentuje prasta r a myśl o wspólnym panowaniu mówiących nad językiem, nad wszelkimi obecnymi w nim alternatywami. Czyli o języku jako twórcy świadomości i s a mo świadomości. Oraz o tym, że 'świadomość' i 'samoświadomość' są nierozdzielne.

\section{Bibliografia}

Ajdukiewicz K., 1965, Logika pragmatyczna. Warszawa: Państwowe Wydawnictwo Naukowe.

Pogonowski J., 1996, On the concept of a linguistic constant, Lingua Posnaniensis XXXVIII, p. 29-38.

Pogonowski J., 1988, Semantic engineering, In: Semiotic Theory and Practice, Berlin - N.Y. - Amsterdam Mouton de Gruyter, p. 899-907.

Pogonowski J., 2003, Po co metalogika lingwistom? w: S. Gajda (red.), Językoznawstwo w Polsce. Stan i perspektywy, Opole, s. 119-126.

A gloss about the question of the existence of "linguistic constants". Is there an ,interpretive constant” 'you know what I mean'?

( s u m m a r y)

The author is considering the possibility of an application of Pogonowski's idea of the existence of certain linguistic counterparts of what is supposed to represent 'logical constants'; such counterparts could be called 'linguistic constants'. Pogonowski has pointed out a number of candidates to the status of such items; one of them is the universal exclusion of inversion as the exponent of negation (I regard the claim to this effect as very plausible). 
The present author's relevant tentative proposition raises the following genuine linguistic move as possibly materializing a 'linguistic constant': it consists in the non-obligatory, but sensible insertion of the phrase 'you know what I mean', Pol. 'wiesz, o czym mówię' in, practically speaking, all utterances. One example of its real use is the well known interpretation of universal quantification as limited to an arbitrary subclass of items whose whole class is officially denoted by the relevant expression currently used by the speaker. Cf., e.g., Everybody in the family knows John has left his home. where the fact that great-grandmother has no idea of the event in no way makes the utterance deviant; the speaker might well have excluded the person from the scope of 'everybody in the family' as used by him.

The author discusses some details of the possible functioning of the indicated phrase (you know what I mean) in the role of a 'linguistic constant'. 